\title{
Self Identity Construction in Rumah Kreatif Wadas Kelir Purwokerto
}

\author{
Rahadian Rizal Akmal ${ }^{1,}$ Mochammad Lathif Amin ${ }^{2,}$ Oom Qomariyah ${ }^{1 *}$, Fika Rizki Nur Fadlillah ${ }^{3}$ \\ ${ }^{1}$ Psychology, Universitas Gadjah Mada, Yogyakarta, Indonesia \\ 2. Philosophy, Universitas Gadjah Mada, Yogyakarta, Indonesia \\ ${ }^{3}$ Management, Universitas Gadjah Mada, Yogyakarta, Indonesia \\ *E-mail: oom.qomariyah@mail.ugm.ac.id
}

\begin{abstract}
This research observes the construction of self-identity in a community called Wadas Kelir Creative House or Rumah Kreatif Wadas Kelir (RKWK) Purwokerto. RKWK is a community focusing on children's creativity development particularly in literacy area. Reasoning and realization of children creativity are built through education pattern, games of language, numbers, logic, colors, art, and fun moves. This place facilitated children with creativity and nice performance even though they come from an unhealthy environment with a high rate of criminality, low education, low economy. This research uses qualitative approach and narrative psychology perspective. Data are collected by using several methods: interview, observation, and documentation. Data analysis involves data reduction, categorization, and synthesis. The narration of children's life stories shows that the process of self-identity construction develops progressively. Self-identity construction is started by implanting the meaning of WKCK which covers various kinds of values: work/creation as a form of self-existence, appreciation towards the whole wide world, and attitudes such as love, dreams, and kindness as human guards. Self-forming is completed through explorations such as self-understanding, self-interest and talent identification by creative games, activities, and experience enrichment. Stage of commitment as a stage approaching identity maturity is accomplished through determination towards dreams, optimism in pursuing the future, and appreciation to the value of 'unlimited creativity'.
\end{abstract}

Keywords: self-identity, meaning of life, Wadas Kelir Creative House

\section{Introduction}

The environment is one of the factors which affect the forming and development of an individual behavior, both natural and social environment (Kulsum, 2014). A child which is bred in a healthy environment, full of love and nice guidance will result as a qualified individual (Purba, 2014). In reverse, a child bred in an unhealthy environment might result in an unqualified individual who does not have a certain life purpose. The unhealthy environment such as low education and economy and high rate of criminality can affect children's behavior. Peer group might have a significant contribution to one's attitudes. When a kid has friends who smoke, he will probably be a smoker too, especially when there is no supervision from the parents (Komasari \& Helmi, 2000).

John Locke introduces a blank slate concept which reveals the significance of experience and life environment toward children's growth. Anastasi (1958) says factors such as environment and heredity either work separately or simultaneously to influence the development of children behavior. In remote areas, there will probably be somebody who actually has a remarkable talent in arts. However, as the environment is incapable enforcing him to develop, his talent will remain invisible (Gunarsa \& Gunarsa, 2008). 
Kids are the next generation to expectedly be agents of change in every era. Realization towards the importance of education for kids in an unhealthy environment has wakened up a community figure named Heru Kurniawan. He initiated a community called Rumah Ajaib (Magic House) in 2012. Rumah Ajaib becomes a place for kids to learn, play, and expand creativity, particularly in literacy area. This community has the vision to create Indonesian kids to be smart, creative, and have strong characters. Later, this community changes its name to be Rumah Kreative Wadas Kelir (RKWK) - Wadas Kelir Creative House, referring to its address which is located on Jalan Wadas Kelir, Karangklesem, Purwokerto. RKWK's choice to focus on children's creativity goes parallel/hand in hand? with J.P. Guilford's view (1950) which states that creativity is one of the aspects of cognitive function which plays its role in children's performance in school. Besides, creativity also needs to be expanded to optimize children's potentials to the fullest (Desmita, 2013).

Creativity is a mental process which is done by an individual as an idea or new product, or the combination of both, which in the end remains in oneself (Gallagher in Rachmawati, 2005). Creativity contributes to supporting one's life to sustain. Creative lifestyle habituates an individual to think innovatively and see every problem from the various point of views (Munandar, 2002).

This creative behavior development in children is very much affected by its circumstance, mainly by family, school, and neighborhood. Wadas Kelir neighborhood which initially was an ex-bus station area with high rates of thuggery and criminality, also low education and economy, is a real challenge for RKWK. On the other hand, creativity is not something to learn from teachers. Teachers can only direct the skills to some extents to kids, for instance how to think creatively and techniques to bring up original ideas. Teachers can only encourage creativity to appear, nourish, and stimulate its growth (Desmita, 2013).

To solve this problem, RKWK applies education pattern and games of language, numbers, logic, colors, music, and moves wrapped in such fun manners. Children's skills and intelligence are developed from its cognitive, affective, and psychomotor aspects (Laely, 2016). Habits of reading, writing, and appreciating literary works are implanted into kids' daily lives which is developed by establishing reading communities which are Taman Bacaan Masyarakat (TBM) Wadas Kelir, Kelir Studio, and Warung Literacy.

This effort turns out well with the emerge of creative and smart kids despite their unhealthy environment. Until now RKWK has been creating kids with remarkable achievements through their works of poems, verses, drawings, and short stories many of which have been published in local and national newspapers such as Radar Banyumas, Kedaulatan Rakyat, Kompas, Bobo, Satelitpost, Solopos, and Suara Merdeka. Other than that, children of RKWK community has several times been awarded in literacy areas such as poetry recital competition, poetry, and short story competition, besides their participation in events in district to national levels. Through both reading and writing stories, kids are invited to internalize the meaning of life and the social and culture values in order to create inspiring individuals with strong identities and nice characters.

This is interesting for the researcher to explore? the meaning of life seeded in RKWK which successfully change ordinary children in Wadas Kelir who are surrounded by such an unhealthy environment and turn to be creative kids with strong identities. Meaning of life is the one which becomes the basis of self-identity construction of those children.

This research aims to explore the meaning of a life of RKWK children which contributes to form their 
identities. Moreover, this research also aims to reveal how self-identities of RKWK children are built and developed. This research is important for its potential to dig out the concepts of creative reasoning development, realization of self-potential, personal identity, enrichment of oneself, its character, and behavior, chiefly? in children and young-adult, in contemporary social life whose identity and culture become more and more biased. In addition, this research is able to be a model of the development of self-identity construction for other communities, a model of character building and mental revolution for Indonesian people, which in the end will reach and involves other areas of people's lives such as politics, economy, social, and culture.

\section{Methods}

\section{Subjects}

Research subjects are RKWK community's children which already has a creative work and have joined RKWK since it was established. Subjects are chosen by using purposive sampling technique, where subjects are registered based on research's criteria and requirements (Arikunto, 2010). Those criteria are; 1) those who are active and have been following the process in RKWK since the establishment up until this research is conducted; 2) young-adult (between 14-16 years old), because this age period is in the peak of self-defining and active seeking for new things (Marcia, 1993); 3) those who already have a creative work, which can be in a form of poem, short story, article, and such, this criterion aims to see the tendency of one's life vision, also the dynamics of the meaning of life and self-identity owned by each kid. The researcher decided the subject from the FGD with their significant others, who are volunteers who teach the children every day. From the FGD, we decided five children to be the subjects.
Research Design. This research uses a qualitative approach, whose research procedure results in descriptive data as in written or spoken data from interviewees and attitudes to be watched over (Moleong, 2010). This approach is chosen for its flexibility and adaptability facing various facts found in the field. Methods of collecting data used are the interview, observation, and documentation. Interviews are done toward chosen subjects with purposive sampling technique, where subjects are registered based on research's criteria and requirements (Arikunto, 2010). The interviewer used semistructured method for the interview. In the observation, we used a nonparticipative method to see their activity naturally. Then, we collected the documents (poem, short story) to dig out the meaning of their life.

The data in this research are analyzed by using a constant comparative method, an analysis which constantly compares one datum with another, and later constantly compares one category to another (Moleong, 2010). Analysis process encompasses: 1) Data reduction, which is done by identifying data, later giving code to each so that the source of each data can be tracked easily; 2) Categorization, which is done by sorting out each analyzed datum into parts which have similarities; 3) Synthesis, which is done by finding relation between one category and another. The researcher also uses interpretation and hermeneutics techniques toward the creative works and narration of the subjects. These methodical elements are used in order to get deep results over one problem or reality beyond some phenomenon. Interpretation is a method to discover meanings deep inside the reality as research objects who are hard to be approached and understood to become easier to get and comprehend (Kaelan, 2005). Meanwhile, hermeneutics is a method to seek and find meanings carried in research objects in a form of phenomena of human life through understanding and interpretation (Kaelan, 2005). 


\section{Results}

Table 1.

Summary of subjects' narration

\begin{tabular}{|c|c|c|c|}
\hline & Beginning Part & Middle Part & Ending Part \\
\hline Explanation & $\begin{array}{l}\text { Some of the subjects are shy } \\
\text { and unconfident kids to } \\
\text { appear or perform in front of } \\
\text { a public. Majority of the } \\
\text { subjects do not like to write, } \\
\text { read, and learn? Bahasa } \\
\text { Indonesia. Besides, subjects } \\
\text { do not have activities in the } \\
\text { afternoon so they only watch } \\
\text { TV and play in their houses. }\end{array}$ & $\begin{array}{l}\text { Subjects have joined RKWK and } \\
\text { started to adjust themselves. } \\
\text { Majority of subjects prefer } \\
\text { reading and writing. Subjects like } \\
\text { to play in RKWK for the games } \\
\text { given are various and once in a } \\
\text { while, they are invited by the } \\
\text { initiator of RKWK to take a walk } \\
\text { in order to find inspiration to } \\
\text { create works in a form of a poem, } \\
\text { short story, or such. }\end{array}$ & $\begin{array}{l}\text { The whole subjects are able to } \\
\text { create works in a form of poems } \\
\text { and much of which has been } \\
\text { published by various mass } \\
\text { media. In addition, subjects have } \\
\text { also published a book of poems } \\
\text { collection. Subjects become } \\
\text { more confident, therefore they } \\
\text { bravely make an appearance in } \\
\text { front of the public. In school, } \\
\text { subjects are often asked to help } \\
\text { their friends writing poetry. } \\
\text { Subjects already have dreams to } \\
\text { pursue. }\end{array}$ \\
\hline
\end{tabular}

Based on the data collected from the interview and categorization, the narration of children from Table 1 can be mapped into 3 sequences, which are the beginning part, middle part, and ending part. The sequences refer to the three staged classification by Gergen and Gergen (1984). The beginning part reveals the situation before subjects join RKWK community, middle part reveals situation during the process in RKWK, and the ending part reveals the change of experienced by subjects in RKWK, also their dreams and orientation towards the future.

\section{Discussion \& Conclusion}

Discussion. Self-identity construction is a combining process of experience, beliefs, and identification collected as a kid into a unique integration and will be more or incoherent, which will provide youngadults both attached in feeling the past and direction to the future (Marcia, 1993). This means that in the process of self-identity forming there are aspects that happened during the phase as a kid such as an experience, beliefs, and identification which become the foundation of identity-forming during the youngadult phase which will give direction to the future and also a yarn connecting to the past.

To see the growth of children, their narration can be arranged sequentially. The narration shows the dynamics of life-meaning which affects self-identity forming process of the subjects. Life-meaning is not connected to things or substance; only connected to activities. In this case, understanding towards chronological order is very important. Therefore, such valid self-experience elaboration shall result in comprehension between temporality and identity (Takwin, 2007).

In general, five narrations of the subjects are all progressive, meaning that there is an effort approaching the goal (Smith, 2014). Subjects have a goal to be creative by creating many writings and experiencing changes to be better. Subjects get chances to find their own talents by various creative games, guided to enhance those talents. Subjects also get mental encouragement, so they feel more confident. Other than that, the spirit to explore is also found in the subjects, inferring to the existence of self-identity forming process. This process is influenced by the meaning of life planted in RKWK. Based on Michael Murray (2015), other than giving order and meaning in daily life, narration also provides structure to individual feeling. The narration is later told to one own's self and other people. Thus, there has been created narrative 
identity through self-definition revealed by that narration (Smith, 2014). Self-identity has a connection with the meaning of life. Meaning of life is also source and basis of self-identity construction.

\section{The Meaning of Life Implanted in Wadas Kelir Creative House}

Meaning of life is something somebody considers as important, precious, and believed to be something right and give special value and thus is worth to be a life goal. Meaning of life shows that there are life goals inside which are things to be reached and to be fulfilled (Frankl, 2004). RKWK delivers the meaning of life to be embedded to the children through games being held, and from the utterance spoken by the initiator of RKWK to the children. There are three values as sources of the meaning of life in RKWK: Creative Values, Experiential Values, and Attitude Values.

\section{a. Creative Values}

RKWK very much emphasizes the importance of creation for someone. RKWK tries to invent people to be creators, not merely workers. Creative value becomes the soul to drive every human activity. Children are invited to create in spite of the limited facility in a form of either poem, sculpture, music, or short movie.

Besides, RKWK also has a culture to appreciate people's creation. All works are appreciated and also given constructive critics so that the children are encouraged to create more and better. Other than appreciation, there is a monthly star-rating system, where the best work will get points. The one who gets the most stars will get a special prize by the initiator of RKWK. This system encourages the children to compete, by creating their best works.

b. Experiential Values

This value is related to one's acceptance of the world. RKWK opens up children's realization that this world is great and beautiful. This realization acts to open children's horizon and spirit of creativity to continue their study and reach their dreams. RKWK can reveal this realization through the close and intimate relationship between the initiator of RKWK, volunteers, and children. Their relationships are horizontal and not vertical. Therefore, heart-to-heart communication is easy to make. Stories being delivered are easily internalized in children's mind. Those children are welcomed to dream about anything. Children are driven to 'get out' of Wadas Kelir. Learning activities are directed to games which take the children closer to their surroundings: taking a walk to many places and writing poems or stories from things around. RKWK increases children's appreciation towards the world deeper. Children are invited to have adventures exploring the wide world without losing their love to where they come from, which are Wadas Kelir and Indonesia.

c. Attitude Values

Creative values and experiential values give direction to the attitude values of RKWK children. Attitude values teach children to be a creator with unlimited ideas. Sometimes, being creative drives people 'crazy'. Crazy here means to think beyond mainstream perspective in facing problems. This value is planted through retelling the stories of inspirational figures' lives delivered in every activity. From those stories, children can learn how to solve problems in life. Appreciation towards the world implanted by RKWK encourages children to think positive in their lives. As what being said by Heru, "act nice to anybody, do willingly, for those nice things will guard us and our descendants. 


\section{Self-Identity Construction of Wadas Kelir Creative House's Children}

The forming of self-identity is a process combining experience, beliefs, and identification gained as a kid into a unique integration and become more or incoherent, which will provide young-adults both attached in feeling the past and direction to the future. This means that in the process of self-identity forming there are aspects that happened during the phase as a kid such as an experience, beliefs, and identification which become the foundation of identity-forming during the young-adult phase which will give direction to the future and also a yarn connecting to the past. Marcia (1993) says the forming of selfidentity is mapped through identity status based on the existence of exploration (crisis) and commitment. The self-identity construction of Wadas Kelir Creative House children can be seen as follow.

\section{a. Exploration (Crisis)}

Exploration, also known as a crisis, is a period of time where somebody wants to get to know about anything, observes every possible choice, actively and seriously asks to reach a decision about life goals, values, and beliefs (Marcia, 1993). The stage of exploration in Wadas Kelir Creative House is done by various kinds of games. One of the principles and methods are chosen to shape and develop self-identity for RKWK children is "learn to play, play to learn". Creative games in the forms of language, logic, colors, and moves are practiced in order to dig out the children's potentials, abilities, interests, and talents. These six games refer to the kinds of human intelligence. This method aims to introduce children to their self-understanding. Children are invited to explore their strengths and weaknesses, also their interests and talents. Subjects can understand themselves through RKWK's challenges and skills development such as singing, writing, drawing, dancing, and many others, seeking for children's interests and talents through creative games. RKWK creates new creative games every day. "Seems like they only play in RKWK, in fact, they don't, we're not only playing, we get many benefits, get knowledge, and also can learn many things, maybe other people takes that aside but we don't," subject says.

This exploration tries to reveal children's realization of their true selves deeper. This realization is not only built on the level of being-to-be, instead, it is brought to the level of allowed-to-be (realization of freedom to be anything we want). This kind of freedom is brought through dreams, also literary and artwork, such as poems, short stories, folktales, music, dance, painting, and drama. Through development in this field, children are welcome to imagine and get out of their selves to wander freely.

Emotional stresses experienced by the children through those games will lead them to their interests and talents. The emerge of happy feeling, worries, and enthusiasm give a tendency to the choices they choose in the future. Ascertain activities are chosen, it eventually reveals their choices and tendency of what they will become in the future.

Stage of exploration does not occur in a flash as an adolescent is a phase of growth with high emotional turmoil and full of passion to try many things. This is a moment of the unstable period with many options. Therefore, this stage occurs dynamically and needs a long process.

b. Commitment

Commitment is a period of decision-making where somebody relatively makes the same choice in many aspects, revealing his true 
identity and involves in activities which significantly directs him to the realization of the choice taken (Marcia, 1993).

Commitment in children built after a long period of exploration. RKWK children begin to decide their choices. They begin to decide goals, dreams, beliefs, purposes, and values. Children finally find detail, clear, and accurate understanding of those things. Commitment can be seen from how sure they are about their goals and dreams, their projection about future, and their unlimited creativity. Subjects are encouraged to dream to be anything, "I want to be a well-known female poet in Indonesia on the same level as Chairil Anwar. Pak Guru (male teacher) said we are able to be anything for when there is a will there is a way," says one subject. Subjects are invited to project their future, starting from their education until their career. "After graduating, I want to continue my study in SMA 5, then enroll to UGM majoring psychology or Indonesian literature. I want to be a journalist or psychologist because I like to talk," says another subject. Subjects are welcomed to burst out their creativity without limits so they can freely and without hesitancy explore it. "We've been like crazy people since joining RKWK. We have to be brave to think out of the box, prohibited to be empty-headed when facing problems. I was sane once I quitted but then remains insane as I come back (to RKWK). But I'm happy," says another one.

Activities are recently led to the chosen aspect of identity. This commitment directs to expression and realization from the choice taken. Again, creation becomes the most dominant point here. Creativity is continuously developed by adjusting the children's fields. Emotion is expressed with confidence, stability, and optimism towards dreams. Realization of being-allowed-to-be becomes stronger and stronger.

Children start to identify themselves with important figures as examples and idols. One of them is their own teacher (Heru Kurniawan). In the case of creativity, he is their role model. Heru's spontaneity, creativity, and ability to live creatively flow in their blood. Values delivered by Heru become a key for the children to work and pursue their dreams or grab their selfidentity as they want with slogans such as "creative "till death" or "go beyond your limits". Figures who are considered as great writers such as Chairil Anwar, Sutardji Bachri, and Sapardi Djoko Damono become their idols and role models of writing-styles.

Children begin to project their future. First, through dreams and goals. The aspect of identity being chosen will be reflected in their ability to project themselves to the future and describe types of activity for several years ahead. RKWK children make maps of their future lives.

One thing shall not be forgotten about at this stage is the existence of creative reasoning in keeping a commitment. Creativity is blown to be the fortress in facing problems and obstacles. They are okay to be 'crazy' as long as it leads them to positive things. Craziness in viewing things from different perspectives will enrich them so they can live in a crunchy, fresh, and colorful life. Children are reminded to always play as kids' world in the world to play. During the stage of exploration, children are still strongly encouraged to play various kinds of games each day to gain an understanding of themselves. Later, they enter commitment stage with life-mapping and the internalization of "unlimited creativity" so the children will continuously work on their field adjusting their interests and talents. 
Conclusions. The meaning of life planted in Wadas Kelir Creative House acts as the basic construction of self-identity which consists of three values: (1) creative values as manifestation of self-existence and soul to somebody's life, (2) experiential values over unlimited world, and (3) attitude values in the forms of love, dream, and kindness as compass and guard of human life. Narration and story of a life of RKWK children show a process of forming selfidentity construction which moves forward (progressive). Construction process starts with selfexploration, self-understanding, a search of interest and talent through creative games, activities, and experience enrichment. Commitment stage is a stage towards identity maturity, to be kept and going through with beliefs to reach dreams, optimism about future, and internalization of 'unlimited creativity' as a value to answer life problems and obstacles.

\section{References}

Anastasi, A. (1958). Heredity, environment, and the question "How?". Psychological Review, 65(4), 197.

Arikunto, S. (2010). Prosedur Penelitian Pendidikan. Jakarta: PT Rineka Cipta.

Crossley, M.L. (2000). Introducing Narrative Psychology. In: Narrative, Memory and Life Transitions. Huddersfield: University of Huddersfield

Desmita. (2013). Psikologi Perkembangan. Bandung: Rosda Karya

Frankl, V.E. (2004). Mencari Makna Hidup. Man's Searching Meaning terjemahan Lala Herawati Dharma. Bandung: Nuansa

Gunarsa, S.D. \& Gunarsa, Y.S.D. (2008). Psikologi Perkembangan Anak dan Remaja. Jakarta: PT BPK Gunung Mulia

Hamidi. (2008). Metode Penelitian Kualitatif. Malang: UMM Press

Kaelan. (2005). Metode Penelitian Kualitatif Bidang Filsafat. Yogyakarta: Paradigma

Komasari, D., \& Helmi, A.F. (2000). Faktor-faktor penyebab Perilaku Merokok pada Remaja. Jurnal Psikologi. Universitas Islam Indonesia \& Universitas Gadjah Mada
Kulsum, U., \& Jauhar, M. (2014). Pengantar Psikologi Sosial. Jakarta: Prestasi Pustaka

Laely, T.A. (2016). Pengembangan Kecerdasan Bahasa pada Anak-anak melalui Permainan Kreatif di Wadas Kelir Purwokerto. Skripsi. IAIN Purwokerto, Purwokerto

Marcia, J.E., et al. (1993). Ego Identity. A Handbook for Psychological Research. New York: Springer Verlag.

Moleong, L.J. (2010). Metode Penelitian Kualitatif. Bandung: Remaja Rosda.

Munandar, U. (2002). Pengembangan Kreativitas Anak Berbakat. Jakarta: Rineka Cipta

Murray, M. (2015). Narrative psychology. Qualitative Psychology: A Practical Guide to Research Methods, 85-107.

Purba, A. (2014). Dampak Kenakalan Remaja dalam Perspektif Kriminologi di Kota Medan. Skripsi. Universitas Sumatra Utara, Medan

Rachmawati, Y., \& Euis, K. (2010). Strategi Pengembangan Kreativitas pada Anak Usia dini Taman Kanak-kanak. Jakarta: Kencana

Smith, J.A. (2014). Psikologi Kualitatif Panduan Praktis Metode Riset. Yogyakarta: Pustaka Pelajar

Takwin, B. (2007). Psikologi Naratif. Yogyakarta: Jalasutra. 